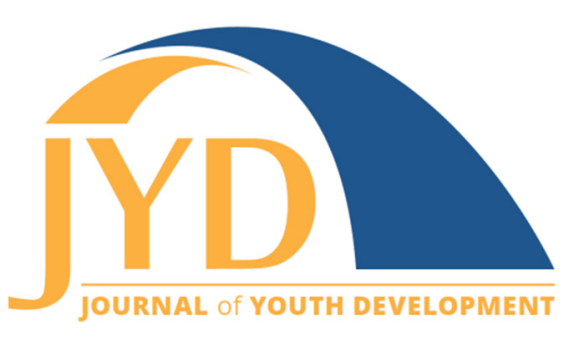

http://jyd. pitt. edu/ | Vol. 13 Issue 4 DOI 10.5195/jyd.2018.617 | ISSN 2325-4017 (online)

\title{
AgVenture: Establishing the Link Between STEM and Agriculture
}

\author{
Becky Ridgeway \\ University of Maryland Extension \\ bridgewa@umd.edu \\ Virginia Brown \\ University of Maryland Extension \\ vbrown12@umd.edu
}

\begin{abstract}
Science, technology, engineering, and math (STEM) education is an integral part of primary school curriculum. AgVenture allows Extension to teach $4^{\text {th }}$ graders about the connection between STEM and agriculture. Extension educators in Maryland developed hands-on activities around animals, plant sciences and nutrition, while linking station-specific activities back to STEM standards. Pretests and posttests show a statistically significant change in STEM-related knowledge by students, while feedback from teachers demonstrates the educational value of the program. Because of these results, AgVenture has grown and now has a waiting list of interested schools. The success of the AgVenture program can be replicated in other Extension programs throughout Maryland and nationwide.
\end{abstract}

Key words: STEM education, AgVenture, elementary school, experiential learning

\section{Literature Review}

STEM education is an approach used to teach students science through the integration of Science, Technology, Engineering and Math into school curriculum (Maryland State Department of Education [MSDE], 2012). The U.S. Department of Education requires the integration of STEM education in all public schools. The standards are designed to build on and reinforce one another, with the goal of preparing students to pursue secondary education and careers in the sciences (U.S. Department of Education, 2015). Each state is responsible for adopting and

(cc) EY $_{\text {EY }}$ New articles in this journal are licensed under a Creative Commons Attribution 4.0 License. This journal is published by the University Library System, University of Pittsburgh and is cosponsored by the University of Pittsburgh Press. The Journal of Youth Development is the official peer-reviewed publication of the National Association of Extension 4-H Agents and the National AfterSchool Association. 


\section{AgVenture: Linking STEM to Agriculture}

integrating STEM standards into the schools. Several states, including Maryland, Pennsylvania, North Carolina, and Illinois, partner with outside organizations to enhance the curriculum offered to provide a wide perspective of how STEM standards can be applied in a real-world setting (MSDE, 2014; Science Foundation Arizona, 2016; I-STEM Education Initiative, 2016; NC STEM Center, 2016; ASSET STEM Education, 2016).

One partnering organization is the Cooperative Extension Service. Extension youth programs target kindergarten through $12^{\text {th }}$-grade youth (Campbell, Wilkenson, \& Shepard, 2014; Campbell, Wilkenson, Shepard, \& Gray, 2015; Dillivan \& Dillivan, 2014; Horton, Krieger, \& Halasa, 2013; Meyer et al., 2014; Sallee \& Peek, 2014; Sallee et al, 2015) through agriculturalbased lessons and programs to enhance STEM knowledge and skills. For example, AGsploration offers a 24-lesson, peer-reviewed curriculum that targets middle school youth (Barczewski, Bennett, Gordon, Hutson, \& BhaduriHauck, 2016) using a variety of methods to reach middle school students; this includes a train-the-trainer component for middle school teachers and extension educators.

AgVenture is a comprehensive program used to enhance fourth-grade students' STEM knowledge through agriculture. Different versions of AgVenture have been delivered in multiple formats and venues to meet the specific needs of the community. For example, Texas (Luckey, Murphey, Cummins, \& Edwards, 2013) uses rodeos to expose youth to the animal sciences, while the University of Arizona has established a year-long program with each season devoted to a specific agricultural subject (University of Arizona, 2015a). In Carroll County, the AgVenture program targets five areas of agriculture (soil/crop production, watersheds, poultry, cattle, and grains/nutrition) at the local Extension office. Similar to Virginia Tech's Agricultural Awareness Days (Campbell, Wilkenson \& Shepard, 2014), Carroll County's AgVenture uses a station approach to provide hands-on learning, reinforcing the lessons and tenets of STEM education.

\section{Methods}

\section{History of AgVenture in Carroll County}

The impetus for AgVenture came from the local Farm Bureau, which wanted to have outreach events for the community. A group of Extension Educators and Farm Bureau volunteers went into the schools to present both the technical and personal sides of agriculture. This evolved into a field trip for fourth-grade students in order to better manage the program and reduce the burden on volunteers, and has remained a field trip opportunity for fourth graders from 2013 to 


\section{AgVenture: Linking STEM to Agriculture}

the present. From 2014 to 2016, the program had five main stations: egg/poultry, dairy, grain, and nutrition. Impact was assessed informally through a show of hands of students' agreement with different questions both before and after the program.

AgVenture had a long history in Carroll County until 2008, when staffing changes caused it to halt. The program was re-conceptualized in 2013 through the work of two 4-H faculty Extension educators, who worked together to develop a program integrating agriculture and Maryland STEM standards for fourth-grade students. Their experiences with school-based 4-H programming allowed them to recruit new schools to participate in AgVenture. Finally, all educators in the University of Maryland Extension Carroll County office, regardless of discipline, work together to teach AgVenture.

Carroll County Extension partners with local community stakeholders and organizations within agriculture to provide real-life examples of how technology and agriculture intersect. For example, a local agricultural equipment dealer provides the use of a combine, tractor and planter so the students can see how the latest technology is used in producing their food, while the local Farm Bureau provides funds to purchase the Maryland agriculture literacy books. The Maryland Grain Producers Utilization Board provides grant funding to cover the cost of transportation and program materials. Table 1 summarizes the donations and support received from the community.

Table 1. Donations and In-Kind Support from Community Partners

\begin{tabular}{|l|l|}
\hline Monetary donors & Monetary donations \\
\hline Local agriculture commodity group & $\$ 2,000$ \\
\hline Farm Bureau & $\$ 200$ \\
\hline In-kind donors & In-kind donations \\
\hline University Research Center & Poultry traveling kit (chickens, chicken house, feed, eggs, poster, etc.) \\
\hline Agriculture center & 4 buildings, 2 animal pens \\
\hline Farm store & 10 bags pine shavings for animals pens \\
\hline Farm equipment dealer & Combine, tractor, planter \\
\hline Feed dealer (2) & Grains (corn, soybeans, oats, barley and wheat) \\
\hline Local producers (3) & Grains (corn, soybeans, oats, barley and wheat), Animals (dairy calf) \\
\hline
\end{tabular}




\section{Recruitment of Schools}

Schools are recruited for participation via a tiered process. AgVenture is first offered to the county's three Title I schools. Title I schools are targeted first as this allows the program to reach at-risk youth who may not have the same opportunities available to them as the other school youth. Title I schools are given a 2-week deadline to decide if they want to participate. After the deadline, the program is opened to schools that previously participated. Finally, the program is opened to all remaining elementary schools. A brochure advertising the program and its success is sent to fourth-grade teachers and school principals. The schools are accepted based on a first-come, first-served policy until the program reaches capacity. In 2014 the program was held for the three Title 1 schools; it expanded in 2015 to include five schools and in 2016 eight schools participated in the program.

\section{Flow of the Day}

AgVenture is a 4-hour long station rotation program held in the spring. From 2014 to2016, students experienced five hands-on stations that tied into a review of or an introduction to fourth-grade science curriculum. Students spent 30 minutes at each station, consisting of a lecture followed with an experiential learning strategy. Stations are taught by an interdisciplinary group of Extension faculty members. Table 2 includes a description of each station and its hands-on activity, along with the STEM standard(s) (MSDE, 2014) addressed at each station.

Historically, 4-H programming has used experiential learning as its principle teaching method. Experiential learning is a process where students are given the opportunity to apply new knowledge gained (Kolb, 1984). This differs from traditional teaching methods where students play a passive role in education. Students are given the knowledge and then the ability to apply it in a real-world setting. One example comes from the livestock station. Students were given three small plates one each containing whole milk, 2\% milk, and skim milk. Using a cotton swab dipped in liquid soap, the students were able to see which milk sample had the highest and lowest fat content based on the displacement of milk around the area touched by the cotton swab. Research shows that experiential learning better prepares students for postsecondary education and careers. 
AgVenture: Linking STEM to Agriculture

Table 2: Integration of STEM Standards Into AgVenture Curriculum

\begin{tabular}{|c|c|c|c|}
\hline Station & Station description & Hands-on activity & $\begin{array}{l}\text { MSDE STEM } \\
\text { Standards of } \\
\text { Practice met }\end{array}$ \\
\hline Grain Nutrition & $\begin{array}{l}\text { Explore the roles whole grains } \\
\text { play in our daily health. }\end{array}$ & $\begin{array}{l}\text { Create whole grain trail mix } \\
\text { Create grain jar. }\end{array}$ & $3 \mathrm{E}$ \\
\hline $\begin{array}{l}\text { Layers! Broilers! } \\
\text { Chicks! }\end{array}$ & $\begin{array}{l}\text { Discover the importance of the } \\
\text { poultry industry to the Maryland } \\
\text { economy. }\end{array}$ & $\begin{array}{l}\text { Investigate feed grains, eggs, } \\
\text { and chicken care. }\end{array}$ & $3 \mathrm{~A}$ \\
\hline $\begin{array}{l}\text { Livestock } \\
\text { RoundUp! }\end{array}$ & $\begin{array}{l}\text { Explore differences in beef and } \\
\text { dairy cattle production. }\end{array}$ & Tie dye milk & $1 \mathrm{~A}$ and $3 \mathrm{C}$ \\
\hline Soil Isn't Just Dirt! & $\begin{array}{l}\text { Learn and identify differences in } \\
\text { soil profiles, organic matter and } \\
\text { equipment technology. }\end{array}$ & Plant zucchini seeds. & $2 \mathrm{~A}$ \\
\hline Watersheds & $\begin{array}{l}\text { Discover how community } \\
\text { members have an impact on } \\
\text { your local watersheds. }\end{array}$ & $\begin{array}{l}\text { Create and observe effects on } \\
\text { watersheds and implement } \\
\text { best management practices. }\end{array}$ & $2 \mathrm{~A}$ and $3 \mathrm{~F}$ \\
\hline
\end{tabular}

\section{Data Collection}

IRB approval was obtained to administer pre- and post-program quizzes to fourth-grade students participating in AgVenture. Each parent received a letter notifying them of the data collection and giving them the opportunity to opt their child out of the study. It is important to note that children were able to participate in AgVenture even if they were not part of the study. Teachers received a pretest to administer to participating students before attending AgVenture. To maintain anonymity, students were asked to write their initials and birth month on the survey rather than their name. Each school received color-coded pretests to be used in matching with color-coded posttests. Pretests and posttests contained five open-ended questions, with one question pertaining to each station:

- Watersheds - What is a watershed?

- Grain Nutrition - What are whole grains and why are they healthy for us?

- Soil Isn't Just Dirt - What is the difference between soil and dirt?

- Layers! Broilers! Chicks! - In what part of Maryland are the most chickens raised?

- Moo Who? - What are some grains that cows eat so they can produce more milk? 


\section{Results}

From 2014 to 2016 a total of 1,412 fourth-grade students and 182 adult chaperones participated in AgVenture. The students were almost evenly split between males (48\%) and females (52\%). Of those that participated, 85\% were Caucasian, 6.6\% African American, 3.3\% Asian and $5.7 \%$ two or more races.

Of the 1,412 students, 943 took both the pre-program and post-program quizzes. One school was lost from this study because the teachers did not provide the pre-program quizzes, while some of the other schools did not have both a pretest and posttest for all students. Finally, six parents opted their children out of the study.

Table 3 summarizes the changes in students' pretest and posttest agriculture knowledge scores. Paired sample t-tests showed a statistically significant increase in students' knowledge in each subject area and overall. The greatest knowledge change was seen in the poultry station, followed by beef and cattle, watershed, grains/nutrition and soil/crop production. Overall, the pretest scores increased from an average of 1.01 points to 4.1 points out of a possible 7 , creating a statistically significant increase at the .001 level.

Table 3. Pretest to Posttest Change in Agriculture Knowledge by Year Surveyed

\begin{tabular}{|l|l|l|l|}
\hline & 2014 & 2015 & 2016 \\
\hline $\begin{array}{l}\text { Pretest mean score } \\
\text { (out of 7) }\end{array}$ & 1.01 & 1.47 & 1.85 \\
\hline $\begin{array}{l}\text { Posttest mean score } \\
\text { (out of 7) }\end{array}$ & Range: $0-4$ & Range: $0-4$ & Range: $0-5$ \\
\hline t-test & Range: $0-7$ & 4.49 & 3.95 \\
\hline
\end{tabular}

Evaluations and feedback from teachers and adult chaperones occurred at the end of AgVenture. All exit surveys showed that the adults in attendance were pleased with the program. Additionally, the individual stations had all positive feedback on the teaching styles and hands-on activities the students engaged in. The most popular among the students was the beef/cattle station; the teachers enjoyed the watershed; and the parents liked the soil station, which included a zucchini planting. Feedback from the students included the following statements:

- My favorite part was seeing, hearing and learning about chickens. 
AgVenture: Linking STEM to Agriculture

- Favorite station that I love best was the station where we got to talk about whole grain and what is healthy for you and when we got to mix snacks in bags. and

- Best field trip ever!

Finally, personal correspondence after the program reveals the continued value teachers see in AgVenture:

- It was AWESOME! I feel like it gets better every year! The kids were amazed at how much they knew and learned as well!

- Our kids had "the best field trip ever" and we would love to come back again next year! Thanks for all you did for us!

- We had a great time. Getting great feedback from parents, teachers and students. Thanks for a great day!

\section{Discussion}

Results from this study show that AgVenture is successful. All students showed an increase in agriculture-related STEM knowledge from pretest to posttest. There was some variability in knowledge gained by subject area. The difference may be attributed to whether or not students had received previous instruction on the topic. For example, the lowest gain was seen in soil and crop production; however, this is likely because they had just finished their lessons on that subject. Similarly, one of the greatest knowledge gains was around watersheds, which is the subject they were just beginning in school.

The success of the program is not just found in the quiz results. During community events and other programs, youth who participated in AgVenture reached out to the educators to tell them how much they enjoyed the experience and their desire to participate again. Teachers and parents report that the children were engaged and loved the program to the point of bragging to family and friends about it. Finally, at least one teacher has requested use of our watershed display to use with students during summer school.

The direct success of the program has led to a positive reputation of the program. Some teachers have gone on to teach at new schools and speak highly of the program, which has led to an increased interest from new schools and new teachers to take part in the upcoming AgVenture year. Carroll County Extension is now exploring additional strategies to meet the need, including offering multiple sessions in one day, expanding the program a second week and putting schools into a rotation where they would participate every other year. 
The success of AgVenture has brought about greater visibility of Extension within Carroll County. At the time of this article, the Carroll County Extension Office had booked 10 schools for the May 2018 AgVenture program, with a potential of reaching 950 to 1,050 students. The value of agriculture education in conjunction with STEM has augmented the teachers' own lessons and excited students about agriculture. This has led to word-of-mouth advertising for the program and even having to limit participation based on the capacity of the facility.

\section{Limitations}

There are a few main limitations to the study. The first is missing data from some of the schools. Consistent with IRB protocol, some students opted out of the research component of the field trip. However, the vast majority of missing data was from one school that did not provide pretest data. This meant that 78 students were not included in the final analysis. While an issue, because of the total sample size used and the reflective diversity of the sample, it is likely there would not have been a significant difference in observed outcomes.

The second limitation was the first-come, first-served policy of the program. Due to limited time, Carroll County Extension was able to accommodate only approximately $39 \%$ of the elementary schools. While efforts were made to reach Title I schools, the rest of the spots were filled based on their response time and our availability to fit them into the schedule. To prevent this from happening in the future, Carroll County is expanding to accommodate 10 schools in 2018. This will allow more students to participate in the AgVenture program during the school year. Another limit to working with the program and scheduling schools can come with the contact teacher moving to another grade or school. This necessitates additional communication with the school to find a new contact person, and holds up the process of scheduling the program for all ten schools. To ensure this doesn't happen, sending out emails at the beginning of the school year can help in contacting all schools as quickly as possible to schedule their date for the following spring.

In moving the program forward in the future, several factors have to be considered with station design. A Carroll County educator routinely compares teaching standards to AgVenture ensuring they are aligned. Furthermore, Carroll County follows regulatory rules set by the Maryland Department of Agriculture when involving livestock in programming. As a result, avian influenza put a halt to having a poultry station in 2016, which led to a decision to discontinue the poultry station from the program. This enabled us to introduce a general livestock production station. 


\section{AgVenture: Linking STEM to Agriculture}

Keeping up to date with curriculum standards has necessitated adjustments to the program to align with standards.

Ensuring the timeline of the planning of the program is a top priority, when coordinating Carroll County Extension Office. Scheduling planning meetings can become challenging when working with multiple educators, agents, and staff members; inviting faculty and staff members through an office calendar system notifies every person in the same manner and also serves to remind attendees about upcoming planning meetings. Contacting any local businesses (farm equipment, livestock farms, etc.) several months before the start of the program to ensure needed material will be available is another preparation that needs to be considered early in the planning process.

\section{Future Directions}

This program serves as a model for how Extension and the school system can partner further. School systems nationwide seek ways to integrate hands-on learning and community organizations into the STEM curriculum. The federal government sets the basic standards, so all states' requirements are similar to those of Maryland (MSDE, 2014) highlighted in this paper. This means AgVenture can be replicated with relative ease and the same marketing and outreach materials can be adapted by other 4-H educators.

Looking ahead, there are many opportunities for AgVenture to grow and be ingrained in the school systems. In Maryland, the General Assembly has pulled together a special committee to investigate the integration of agricultural literacy into lessons on all grade levels. Other states, such as Texas and Arizona, have already begun regional and statewide programs to increase agricultural literacy among youth (Texas A\&M University, 2015; University of Arizona, 2015b). Finally, National Ag in the Classroom and the National Institute of Food and Agriculture (NIFA) released a 2014 report demonstrating the alignment of agricultural literacy benchmarks by federal education requirement and its cross-cutting linkage between STEM, science, health, and social sciences (Spielmaker \& Leising, 2014).

The importance of agricultural education in the classroom is growing and Cooperative Extension is uniquely positioned to address this need. Understanding the links among agricultural systems, health and science can serve to enhance the visibility of Cooperative Extension and lead to greater appreciation and knowledge about what agriculture education can give to our society. 


\section{References}

ASSET STEM Education. (2016). ASSET STEM education: Our program. Retrieved from https://assetinc.org/

Barczewski, A., Bennett, S., Gordon, D., Hutson, T., \& BhaduriHauck, S. (2016). Using the AGsploration: the science of Maryland agriculture curriculum as a tool to increase youth appreciation and understanding of agriculture and science. Journal of Youth Development, 11(3), 141-146. Retrieved from https://jyd.pitt.edu/ojs/jyd/article/view/467

Campbell, B.T., Wilkinson, C. A. \& Shepherd, P. J. (2014). Agricultural awareness days: Integrating agricultural partnerships and STEM education. Journal of Extension, 52(2), Article 2TOT8. Retrieved from http://www.joe.org/joe/2014april/tt8.php

Campbell, B. T., Wilkinson, C. A., Shepherd, P. J., \& Gray, P. (2015). Industry and Extension partnership to enhance STEM and agricultural education. Journal of Extension, 53(4), Article 4TOT6. Retrieved from http://www.joe.org/joe/2015august/tt6.php

Dillivan, K. D. \& Dillivan, M. N. (2014). Student interest in STEM disciplines: Results from a summer day camp. Journal of Extension, 52(1), Article 1RIB5. Retrieved from http://www.joe.org/joe/2014february/rb5.php

Horton, R.L., Krieger, J. \& Halasa, K. (2013). 4-H ChickQuest: Connecting agri-science with STEM standards in urban schools. Journal of Extension, 51(1), Article 1IAW7. Retrieved from http://www.joe.org/joe/2013february/iw7.php

I-STEM Education Initiative. (2016). I-STEM education initiative. Retrieved from http://www.istem.illinois.edu/

Kolb, D.A. (1984). Experiential learning. Englewood Cliffs, N. J.: Prentice-Hall.

Luckey, A. N., Murphey, T. P., Cummins, R. L. \& Edwards, M. B. (2013). Assessing youth perceptions and knowledge of agriculture: The impact of participating in an AgVenture program. Journal of Extension, 51(3), Article 3RIB3. Retrieved from https://www.joe.org/joe/2013june/rb3.php

Maryland State Department of Education. (2012). Maryland state STEM standards of practice framework. Retrieved from http://mdk12.msde.maryland.gov/instruction/academies/mdstem_framework_gradesk-5.pdf

Maryland State Department of Education. (2014). Framework and instructional guide grades K-5. Retrieved from http://mdk12.msde.maryland.gov/instruction/curriculum/STEM/frameworks_k5.html

Meyer, N. J., Scott, S., Strauss, A. L., Nipolt, P. L., Oberhouser, K. S., \& Blair, R. B. (2014). Citizen science as a REAL environment for authentic scientific inquiry. Journal of Extension, 52(4), Article 4IAW3. Retrieved from http://www.joe.org/joe/2013february/iw7.php 
NC STEM Center. (2016). Strategies that engage minds. Retrieved from https://www.ncstemcenter.org/connect/national-stem-portals/

Sallee, J. \& Peek, G. G. (2014). Fitting the framework: The STEM Institute and the 4-H essential elements. Journal of Extension, 52(2), Article 2FEA8. Retrieved from http://www.joe.org/joe/2014april/a8.php

Sallee, J., Schmitt-McQuitty, L., Swint, S., Meek, A., Ybarra, G. \& Dalton, R. (2015). TechXcite: Discover engineering-A new STEM curriculum. Journal of Extension, 53(3), Article 3TOT5. Retrieved from http://www.joe.org/joe/2015june/tt5.php

Science Foundation Arizona. (2016). Arizona STEM network. Retrieved from http://www.sfaz.org/stem/

Spielmaker, D. M., \& Leising, J. G. (2013). National agricultural literacy outcomes. Retrieved from http://agclassroom.org/teacher/matrix

Texas A\&M University. (2015). Agricultural literacy. Retrieved from http://agcj.tamu.edu/105/PDF/Agricultural\%20Literacy.pdf

University of Arizona. (2015a). Agricultural literacy. Retrieved from http://calsmac.arizona.edu/educational-programs-mac

University of Arizona. (2015b). History of ag-literacy outreach at the MAC farm. Retrieved from http://cals-mac.arizona.edu/ag-ventures-history

U.S. Department of Education. (2015). Elementary/middle school STEM full implementation. Retrieved from http://www.doe.in.gov/sites/default/files/ccr/elementary-and-middles-school-stemimplementationv2.pdf 